Correspondence

Xavier Foissac

foissac@bordeaux.inra.fr

Received 7 July 2010

Revised 8 September 2010

Accepted 10 September 2010

\section{Multilocus sequence analysis reveals the genetic diversity of European fruit tree phytoplasmas and supports the existence of inter-species recombination}

Jean Luc Danet, ${ }^{1}$ Gulnara Balakishiyeva, ${ }^{2}$ Agnès Cimerman, ${ }^{1}$ Nicolas Sauvion, ${ }^{3}$ Véronique Marie-Jeanne, ${ }^{3}$ Gérard Labonne, ${ }^{3}$ Amparo Laviňa, ${ }^{4}$ Assumpcio Batlle, ${ }^{4}$ Ivana Križanac, ${ }^{5}$ Dijana Škorić, ${ }^{6}$ Paolo Ermacora, ${ }^{7}$ Çigdem Ulubaș Serçe, ${ }^{8}$ Kadriye Çağlayan, ${ }^{8}$ Wolfgang Jarausch ${ }^{9}$ and Xavier Foissac ${ }^{1}$

${ }^{1}$ UMR Génomique Diversité Pouvoir Pathogène, INRA, Université Victor Ségalen Bordeaux 2, 71 Avenue Edouard Bourlaux, BP81, F-33883 Villenave d'Ornon Cedex, France

${ }^{2}$ Institute of Botany, National Academy of Sciences of Azerbaijan, Patamdar shosse 40, AZ-1073, Baku, Azerbaijan

${ }^{3}$ UMR Biologie et Génétique des Interactions Plante-Parasite, CIRAD, INRA, SUPAGRO, Campus International de Baillarguet, TA A-54/K, F-34398 Montpellier Cedex 5, France

${ }^{4}$ Institut de Recerca i Tecnologia Agroalimentaries (IRTA), Ctra Cabrils Km 2, E-08348 Cabrils, Barcelona, Spain

${ }^{5}$ Institute for Plant Protection, Croatian Centre for Agriculture, Food and Rural Affairs, Svetošimunska 25, HR-10000 Zagreb, Croatia

${ }^{6}$ Department of Biology, University of Zagreb, Marulicev trg 9a, HR-10000 Zagreb, Croatia

${ }^{7}$ Dipartimento di Biologia e Protezione delle Piante, Università degli Studi di Udine, via Delle Scienze 208, I-33100 Udine, Italy

${ }^{8}$ Department of Plant Protection, Mustafa Kemal University, TK-31034 Antakya-Hatay, Turkey

${ }^{9}$ AlPlanta - Institute for Plant Research, RLP AgroScience GmbH, Breitenweg 71, D-67435

Neustadt an der Weinstrasse, Germany

The genetic diversity of three temperate fruit tree phytoplasmas 'Candidatus Phytoplasma prunorum', 'Ca. P. mali' and 'Ca. P. pyri' has been established by multilocus sequence analysis. Among the four genetic loci used, the genes imp and ace $F$ distinguished 30 and 24 genotypes, respectively, and showed the highest variability. Percentage of substitution for imp ranged from 50 to $68 \%$ according to species. Percentage of substitution varied between 9 and $12 \%$ for aceF, whereas it was between 5 and $6 \%$ for pnp and secY. In the case of 'Ca P. prunorum' the three most prevalent aceF genotypes were detected in both plants and insect vectors, confirming that the prevalent isolates are propagated by insects. The four isolates known to be hypo-virulent had the same ace $F$ sequence, indicating a possible monophyletic origin. Haplotype network reconstructed by eBURST revealed that among the 34 haplotypes of ' $\mathrm{Ca}$. P. prunorum', the four hypo-virulent isolates also grouped together in the same clade. Genotyping of some Spanish and Azerbaijanese 'Ca. P. pyri' isolates showed that they shared some alleles with 'Ca. P. prunorum', supporting for the first time to our knowledge, the existence of inter-species recombination between these two species.

Abbreviations: AP, apple proliferation; ESFY, European stone fruit yellows; MLST, multilocus sequence typing; PD, pear decline; SNP, single nucleotide polymorphism; SSH, suppression subtractive hybridization.

The GenBank/EMBL/DDBJ accession numbers for the aceF, pnp, sec $Y$ and imp gene fragments isolated in this study are listed in Tables 3-6.

A supplementary table, showing the origin and haplotype of all phytoplasma isolates, is available with the online version of this paper. 


\section{INTRODUCTION}

Phytoplasmas are plant-pathogenic bacteria belonging to the class Mollicutes, a group of wall-less micro-organisms phylogenetically related to low $\mathrm{G}+\mathrm{C}$-content, Grampositive bacteria (Weisburg et al., 1989). They are responsible for hundreds of crop diseases worldwide (Lee et al., 2000) and are transmitted from plant to plant by sapsucking hemipteran insects (Weintraub \& Beanland, 2006). European temperate fruit trees are affected by diseases associated with phytoplasmas which cause important economic losses to the European fruit production. 'Candidatus Phytoplasma prunorum' is responsible for European stone fruit yellows (ESFY) in trees and shrubs of the genus Prunus, 'Candidatus P. mali' is the causative agent of apple proliferation (AP) in those of the genus Malus and 'Candidatus P. pyri' is responsible for pear decline (PD) in Pyrus (Seemüller \& Schneider, 2004). AP affects European and Turkish apple orchards (Seemüller, 1990; Sertkaya et al., 2008) and the highest economical impact occurs in Germany and northern Italy. PD has been reported in Europe, North America and the Middle East (Battle et al., 1999; Blomquist \& Kirkpatrick, 2002b; Choueiri et al., 2007; Davies et al., 1992; Lorenz et al., 1995; Malinowski et al., 1996; Sharbatkhari et al., 2008) and also in Taiwan (Liu et al., 2007). ESFY is present in the Euro-Mediterranean basin (Marcone et al., 2010) and kills $5 \%$ of the apricot trees per year in southern France (Jarausch et al., 2001) due to a severe form of apricot chlorotic leafroll. It also induces plum leptonecrosis on Prunus salicina (Japanese plum) and yellows on most of the peach accessions in southern Europe. These three phytoplasmas belong to the same phylogenetic cluster, the group 16SrX (Lee et al., 2000), and form three closely related subgroups (Jarausch et al., 1994; Lorenz et al., 1994).

'Ca. P. mali', 'Ca. P. pyri' and 'Ca. P. prunorum' are transmitted from tree to tree by psyllids of the genus Cacopsylla (Carraro et al., 1998; Frisinghelli et al., 2000; Jarausch \& Jarausch, 2009; Jensen et al., 1964) and can be propagated by grafting or multiplication of infected material in nurseries. In addition, ' $C a$. P. mali' can also be transmitted through rootbridges among neighbouring trees in an orchard (Ciccotti et al., 2007). Difference in virulence has been shown between isolates of ' $\mathrm{Ca}$. P. prunorum' (Kison \& Seemüller, 2001) and of 'Ca. P. mali' (Seemüller \& Schneider, 2007) giving the first evidence of the biodiversity in this clade of phytoplasmas. In the case of 'Ca. P. prunorum', hypo-virulent isolates of the same species have been reported to occur in France and attempts have been made to use them for cross protection (Cornaggia et al., 1995; Morvan et al., 1991). The biodiversity of ' $\mathrm{Ca}$. P. mali' was recently investigated by singlestrand conformation polymorphism and sequence analyses of the $h f l B$ gene (Schneider \& Seemüller, 2009) as an outcome of the ' $\mathrm{Ca}$. P. mali' genome sequencing (Kube et al., 2008). However, little is known about the genetic diversity of 'Ca. P. prunorum' and ' $C a$. P. pyri'.
In the absence of typing tools, it is not possible to trace the route of propagation of phytoplasma strains. Typing tools are therefore needed to improve disease control. The most appropriate method for genotyping prokaryotes is multilocus sequence typing (MLST) which is widely used in bacterial epidemiology and population genetics (Maiden et al., 1998; Urwin \& Maiden, 2003). However, it requires the identification of gene sequences. For this purpose, and because very few genes have been characterized in this group of phytoplasmas, genes of ' $\mathrm{Ca}$. P. prunorum' were cloned using a subtractive method. To design a multilocus sequence analysis of phytoplasmas of the group $16 \mathrm{SrX}$, four genes were targeted: two genes involved in carbon and nucleotide metabolism and two genes encoding the immunodominant surface protein Imp and SecY, a component of the protein secretion machinery. The results of this investigation are presented with special emphasis on the genetic diversity of ' $\mathrm{Ca}$. P. prunorum'.

\section{METHODS}

Plant material and insects. Reference phytoplasma strains AT, AP15, GSFY2 and PD1 had been transmitted by dodder from fruit trees to periwinkle (Catharanthus roseus $\mathrm{cv}$. Cooler) and since then have been maintained in periwinkle by successive graft inoculation (Carraro et al., 1988; Marcone et al., 1999; Marwitz et al., 1974). Samples from infected Prunus, Malus or Pyrus species were collected from different regions of France, Spain, Austria, Germany, Croatia, Hungary, the UK, Bosnia and Herzegovina, Romania, Italy, Switzerland, Turkey, Lebanon and Azerbaijan (Table 1). Cacopsylla pruni psyllids were collected in Spring on Prunus spinosa (wild Prunus) in France and Spain, and on Japanese plum in Italy, by hitting branches above a lying net (Table 1). Plant DNA was tested by ECA1-ECA2 PCR for 'Ca. P. prunorum' (Jarausch et al., 1998), by AP3-AP4 PCR for ' $C a$. P. mali' (Jarausch et al., 1994) and by universal phytoplasma 16SrDNA nested-PCR (Gundersen \& Lee, 1996) followed by sequencing for ' $\mathrm{Ca}$. P. pyri'. Only positive samples were included in this study.

Double suppression subtractive hybridization (SSH) and genome walking. Double $\mathrm{SSH}$ was performed using the PCRSelect bacterial genome subtraction kit (BD Bioscience) except for the primers and adaptors which were modified as described previously (Cimerman et al., 2006). Total DNA from healthy and GSFY2infected periwinkle $(2 \mu \mathrm{g})$ were digested overnight at $37^{\circ} \mathrm{C}$ by $R s a \mathrm{I}$ (MBI Fermentas). RsaI-digested healthy plant DNA was used as the driver. Two populations of tester DNA were produced by ligating adaptors 1 and $2 \mathrm{R}$ to RsaI-digested DNA of infected plants. Aliquots of the ligation products were hybridized with an excess of driver according to the manufacturer's instructions. These first hybridization mixtures were then hybridized together in the presence of an additional amount of driver. Hybrids carrying both adaptors 1 and $2 \mathrm{R}$ were amplified by nested PCR according to the manufacturer's instructions using Taq polymerase (Promega). PCR amplification was performed in a $25 \mu \mathrm{l}$ reaction volume with $0.4 \mu \mathrm{M}$ primer $\mathrm{P} 1$. The templates were first heated for $2 \mathrm{~min}$ at $72{ }^{\circ} \mathrm{C}$ to fill extremities and then denatured for $25 \mathrm{~s}$ at $94{ }^{\circ} \mathrm{C}$. PCR conditions were 30 cycles $(10 \mathrm{~s}$ at $94{ }^{\circ} \mathrm{C}, 30 \mathrm{~s}$ at $62{ }^{\circ} \mathrm{C}, 1 \mathrm{~min} 30 \mathrm{~s}$ at $72{ }^{\circ} \mathrm{C}$ ) with a single final extension of $7 \mathrm{~min}$ at $72{ }^{\circ} \mathrm{C}$. Twenty identical cycles were used for nested amplification, with the sense and anti-sense primers NP1 and $\mathrm{NP2R}$, and followed by a single final extension of $7 \mathrm{~min}$ at $72^{\circ} \mathrm{C}$. For reverse SSH, DNA from infected plants was used as the driver and DNA from healthy plants was used as the tester. 
Table 1. Origin of the phytoplasma isolates tested

\begin{tabular}{|c|c|c|c|c|}
\hline \multirow[t]{2}{*}{ Country } & \multirow[t]{2}{*}{ Host } & \multicolumn{3}{|c|}{ No. of isolates tested } \\
\hline & & $\begin{array}{c}\text { 'Ca. } \mathrm{P} . \\
\text { prunorum' }\end{array}$ & $\begin{array}{l}\text { 'Ca. P. } \\
\text { pyri' }\end{array}$ & $\begin{array}{l}\text { 'Ca. P. } \\
\text { mali' }\end{array}$ \\
\hline \multirow[t]{2}{*}{ Azerbaijan } & Prunus armeniaca & 2 & & \\
\hline & Prunus myrobolan & 1 & & \\
\hline Croatia & Prunus armeniaca & 8 & & \\
\hline \multirow[t]{7}{*}{ France } & Cacopsylla pruni & 26 & & \\
\hline & Prunus armeniaca & 10 & & \\
\hline & Prunus spinosa & 9 & & \\
\hline & Prunus salicina & 3 & & \\
\hline & Prunus persica & 2 & & \\
\hline & $\begin{array}{l}\text { Prunus mariana } \\
\text { GF8-1 }\end{array}$ & 5 & & \\
\hline & Prunus sp. & 10 & & \\
\hline Germany & Prunus armeniaca & 22 & & \\
\hline Greece & Prunus armeniaca & 1 & & \\
\hline \multirow[t]{2}{*}{ Italy } & Prunus armeniaca & 9 & & \\
\hline & Cacopsylla pruni & 4 & & \\
\hline \multirow[t]{2}{*}{ Spain } & Cacopsylla pruni & 2 & & \\
\hline & Prunus armeniaca & 9 & & \\
\hline Turkey & Prunus armeniaca & 3 & & \\
\hline Azerbaijan & Pyrus communis & & 3 & \\
\hline \multirow[t]{3}{*}{ Croatia } & Cacopsylla pyri & & 2 & \\
\hline & $\begin{array}{c}\text { Cacopsylla } \\
\text { pyrisuga }\end{array}$ & & 1 & \\
\hline & Pyrus communis & & 8 & \\
\hline France & Pyrus communis & & 3 & \\
\hline Germany & Pyrus communis & & 8 & \\
\hline Italy & Pyrus communis & & 6 & \\
\hline Lebanon & Pyrus communis & & 4 & \\
\hline Spain & Pyrus communis & & 5 & \\
\hline \multirow[t]{2}{*}{ Turkey } & Cacopsylla pyri & & 1 & \\
\hline & Pyrus communis & & 2 & \\
\hline UK & Pyrus communis & & 3 & \\
\hline Austria & Malus domestica & & & 1 \\
\hline $\begin{array}{l}\text { Czech } \\
\text { Republic }\end{array}$ & M. domestica & & & 1 \\
\hline France & M. domestica & & & 9 \\
\hline Germany & M. domestica & & & 13 \\
\hline Italy & M. domestica & & & 13 \\
\hline Romania & M. domestica & & & 1 \\
\hline Switzerland & M. domestica & & & 1 \\
\hline
\end{tabular}

For double SSH, adaptors 1 and $2 \mathrm{R}$ were removed from the SSH product by RsaI digestion and replaced by the adaptors 3 and $4 \mathrm{R}$ before proceeding to the second round of subtraction. Then, RsaIdigested SSH product ligated to new adaptors NP3 and NP4 was used as tester and the RsaI reverse SSH product was used as the driver. PCR amplification was carried out with $0.4 \mu \mathrm{M}$ primer P3. Nested amplification of the double $\mathrm{SSH}$ product was performed with primers NP3 and NP4R (Cimerman et al., 2006). One microlitre of the double SSH product was ligated to pGEM-T Easy (Promega) and cloned in Escherichia coli DH10B according to standard procedures (Sambrook et al., 1989).

One of the double SSH clones (SDR47) was extended by genome walking. Extension of the SDR47 sequence was performed using the
Biosciences Clontech BD GenomeWalker universal kit according to the manufacturer's instructions. Libraries for genome walking were composed of endonuclease-restricted DNA of periwinkles infected with 'Ca. P. prunorum' isolate GSFY2.

Extraction of DNA from plants and insects, and PCR amplification. Nucleic acids were extracted from plants and insects as described by Maixner et al. (1995). The aceF, pnp, secY and imp genes were amplified by nested PCR using the primers described in Table 2. First amplifications were performed using an initial denaturation step at $95{ }^{\circ} \mathrm{C}$ for $3 \mathrm{~min}$, followed by 20 cycles consisting of $94{ }^{\circ} \mathrm{C}$ for $30 \mathrm{~s}, 50{ }^{\circ} \mathrm{C}$ for $30 \mathrm{~s}$ and $66^{\circ} \mathrm{C}$ for $45 \mathrm{~s}$, and by a final extension step at $66^{\circ} \mathrm{C}$ for $7 \mathrm{~min}$. Nested amplification was carried out using $1 \mu \mathrm{l}$ of the first amplification product with an initial denaturation step at $95{ }^{\circ} \mathrm{C}$ for $3 \mathrm{~min}$ followed by 35 cycles consisting of $94{ }^{\circ} \mathrm{C}$ for $30 \mathrm{~s}, 50{ }^{\circ} \mathrm{C}$ for $30 \mathrm{~s}$ and $66{ }^{\circ} \mathrm{C}$ for $45 \mathrm{~s}$, and by a final extension step at $66{ }^{\circ} \mathrm{C}$ for $7 \mathrm{~min}$. Nested PCR products were separated on a $1 \%$ agarose gel; DNA was stained with ethidium bromide and visualized under UV light.

Sequencing and sequence analysis. Sequencing reactions of the SSH plasmids and MLST PCR products were performed by Cogenics on ABI PRISM capillary sequencing instruments. Raw sequence chromatograms were assembled and edited using GAP4 (Bonfield et al., 1995) or the PHRED-PHRAP-CONSED package (Ewing \& Green, 1998; Ewing et al., 1998; Gordon et al., 1998). All MLST PCR products were directly sequenced on both strands to achieve a $2 \times$ coverage. Homologies between SSH clone sequences and known sequences were detected using the BLASTX algorithms against the nonredundant GenBank database at http://www.ncbi.nlm.nih.gov/blast. Multiple alignments were performed using CLUSTAL w (Thompson et al., 1994) and the phylogenetic analyses were carried out with MEGA2 (Kumar et al., 2001). Haplotype networks were constructed using the eBURST programme (Feil et al., 2004)

\section{RESULTS}

\section{Double SSH and PCR analysis of phytoplasmas}

A library was constructed by cloning the RsaI double SSH product obtained by double-subtracting the total DNA of healthy periwinkle from the total DNA of a periwinkle infected with ' $\mathrm{Ca}$. P. prunorum' isolate GSFY2. Thirty plasmid inserts with sizes ranging from 536 to $971 \mathrm{bp}$ were sequenced and identified by a BLASTX similarity search as being phytoplasma partial gene sequences. Most of the sequences were redundant in the library and finally corresponded to 11 unique sequences which are listed elsewhere (Danet et al., 2008). The peptides predicted from SSH sequences shared $53-90 \%$ identity with proteins predicted from the ' $\mathrm{Ca}$. P. asteris' genome sequence (Oshima et al., 2004). The sequence downstream of the $a c o B$ (insert SDR47) was determined by genome walking and used to identify the sequence of the neighbouring gene aceF. Among the 'Ca. P. prunorum' genes identified, aceF and $p n p$ were chosen as targets for the variability study because they presented the lowest conservation level when compared with the ' $\mathrm{Ca}$. P. asteris' homologous genes, which had 41 and $53 \%$ identity, respectively, at the predicted protein level. In addition to these two genes involved in sugar and nucleotide metabolism, the two genes secY and imp were selected to drive the genetic 
Table 2. Oligonucleotides used for PCR and nested PCR

\begin{tabular}{|c|c|c|c|c|}
\hline Gene & Length (bp) & Purpose & Primer & Sequence $\left(5^{\prime}-3^{\prime}\right)$ \\
\hline \multirow[t]{3}{*}{ aceF } & 797 & PCR & AceFf1 & TAAAATTCGCTGATGTTGGCG \\
\hline & & & AceFr1 & CATCTTTCAATTCATTAAAACTAG \\
\hline & & & AceFr2 & CAACCGCTTTCATAATAAAAG \\
\hline \multirow[t]{3}{*}{$p n p$} & 549 & PCR & Pnpf1 & GAAGTTGGTATTACTGCTTTAC \\
\hline & & & Pnpr1 & GATAAATCTATTTGACCGCG \\
\hline & & & Pnpr2 & ATTAATTTTAATACATTTCGC \\
\hline \multirow[t]{4}{*}{$\sec Y$} & 664 & PCR & SecYMalF1 & TTAGGACGTAGTATACAAATCCCNTT \\
\hline & & & SecYMalR1 & ACAATAATTAAAAATCCTGTNCC \\
\hline & & Nested-PCR & SecYMalF2 & AAGAATGGCGTGAACARGGNGA \\
\hline & & & SecYMalR2 & GCATCTTGTTTAGATAAATGTTC \\
\hline imp 'Ca. P. prunorum’ & 673 & PCR & IMPF1 & CAAATGATAAAGCTGATCAA \\
\hline \multirow[t]{4}{*}{ imp 'Ca. P. pyri' } & 452 & PCR & IMPF2bis & GTATTTAGTTACAATTATTTACTAG \\
\hline & & & IMPR1bis & CAAGACCTTTAAGGCCACATC \\
\hline & & Nested-PCR & IMPF3pyr & AGGAGAAAAAATAATGGAAGC \\
\hline & & & IMPR4pyrA & TTGTGTTCTAAAAGTATCAC \\
\hline \multirow[t]{4}{*}{ imp 'Ca. P. mali' } & 670 & PCR & IMPF1 & CAAATGATAAAGCTGATCAA \\
\hline & & & IMPR1bis & CAAGACCTTTAAGGCCACATC \\
\hline & & Nested-PCR & IMPF3 & GTTTTATGTTATAATAAACAGTG \\
\hline & & & IMPR3mal & CAAACTATAGTTAAAATTAAAGC \\
\hline
\end{tabular}

diversity study. $\sec Y$ is involved in protein secretion and its sequence was kindly provided by the ' $\mathrm{Ca}$. P. mali' genome sequence consortium (Kube et al., 2008). imp encodes the immunodominant surface protein and had been sequenced for the three species members of the 16SrX group (Morton et al., 2003).

In order to develop a polyvalent PCR test for the entire $16 \mathrm{SrX}$ group, three nested PCR tests were designed from aceF, pnp and secY genes with primer pairs selected in regions encoding conserved domains of the proteins. To check the effectiveness of PCR primers, they were challenged against periwinkles infected with Italian and German ' $\mathrm{Ca}$. P. prunorum' isolates and German ' $\mathrm{Ca}$. P. mali' and ' $\mathrm{Ca}$. P. pyri' isolates. Each primer pair allowed the direct amplification of aceF, pnp and secY DNA fragments for all phytoplasma tested provided that annealing and elongation temperatures were 50 and $66^{\circ} \mathrm{C}$, respectively (data not shown). For imp, due to its important variability among 16SrX phytoplasmas (Morton et al., 2003), species-specific primer pairs had to be designed.

aceF, pnp, secY and imp nested PCR assays were applied to a collection of 197 phytoplasma isolates originating from France, Germany, Italy, Spain, Croatia, Switzerland, the UK, Hungary, Turkey, Greece, Azerbaijan and Lebanon. All samples had previously tested positive for $16 \mathrm{SrX}$ phytoplasmas by $16 \mathrm{~S}$ rDNA PCR diagnosis. Most of the samples (157 of 197) reacted positively for the four nested PCR tests including all the 32 infected Cacopsylla pruni tested (' $\mathrm{Ca}$. P. prunorum' insect vector).

Sequences of the PCR products were determined and compared by multiple alignments. The presence of speciesspecific sequence motifs and important genetic distances were in agreement with the existence of three distinct phytoplasma species. Sequence alignments indicated that four deletions (total $15 \mathrm{bp}$ ) and one $3 \mathrm{bp}$ insertion took place in the ' $\mathrm{Ca}$. P. pyri' aceF sequence by comparison with 'Ca. P. prunorum', whereas five deletions totalling $48 \mathrm{bp}$ distinguished the ' $\mathrm{Ca}$. P. mali' aceF sequence. The proportion of substitutions in aceF ranged from $9.6 \%$ between ' $\mathrm{Ca}$. P. pyri' and ' $\mathrm{Ca}$. P. mali' to $12 \%$ between ' $\mathrm{C} a$. P. pyri' and 'Ca. P. prunorum'. No insertion or deletion occurred in pnp sequences and substitutions affected 5-6\% of nucleotide positions depending on the ' $\mathrm{Ca}$. Phytoplasma' species compared. In the secY gene, sequences diverged about $5 \%$ between species and one $3 \mathrm{bp}$ deletion was observed for 'Ca. P. pyri'.

imp was the most variable gene with 34.3 sequence identity between 'Ca. P. prunorum' and 'Ca. P. pyri', and $32.1 \%$ between ' $C a$. P. prunorum' and 'Ca. P. mali', while ' $C a$. P. mali' and ' $C a$. P. pyri' imp sequences were $50.8 \%$ identical. Two 3 bp deletions took place in imp of ' $\mathrm{Ca}$. P. prunorum'; one 9 bp deletion and two 3 bp insertions characterize imp of ' $C a$. P. mali'; whereas a 3 bp insertion was specific to the 'Ca. P. pyri' imp gene. 


\section{Sequencing ace $F$, pnp, secY and imp identifies geographically related genotypes}

The sequence of the aceF marker was determined for 197 isolates of the three Candidatus species. Maximumparsimony analysis of aceF sequences confirmed the existence of three phylogenetic clusters corresponding to 'Ca. P. prunorum', 'Ca. P. mali' and 'Ca. P. pyri' (Fig. 1, Table 3). For 'Ca. P. prunorum', 11 genotypes were discriminated, most of them differing by one or two single nucleotide polymorphisms (SNPs). Only genotype A9 [an apricot isolate and a Prunus cerasifera (myrobalan plum) isolate from Azerbaijan] presented 10-12 SNPs compared with the other ' $\mathrm{Ca}$. P. prunorum' genotypes. The genotype A3 represented $57 \%$ of infection cases. This genotype was found in isolates from France, Germany, Spain and Italy (Table 3). Two other genotypes, A8 and A6, accounted for 19 and $14 \%$ of the isolates, respectively. These genotypes were detected in isolates from France, Croatia, Germany, Italy, Turkey, Spain, Greece and Azerbaijan (Table 3). Seven aceF genotypes were only found in a single country, for example, genotypes A7, A9 and A17 were only detected in Croatia, Azerbaijan and Turkey, respectively. Interestingly, the four hypo-virulent isolates of ' $\mathrm{Ca}$. $\mathrm{P}$. prunorum' tested (namely PVC-LA8 and PVC-LA9, B7

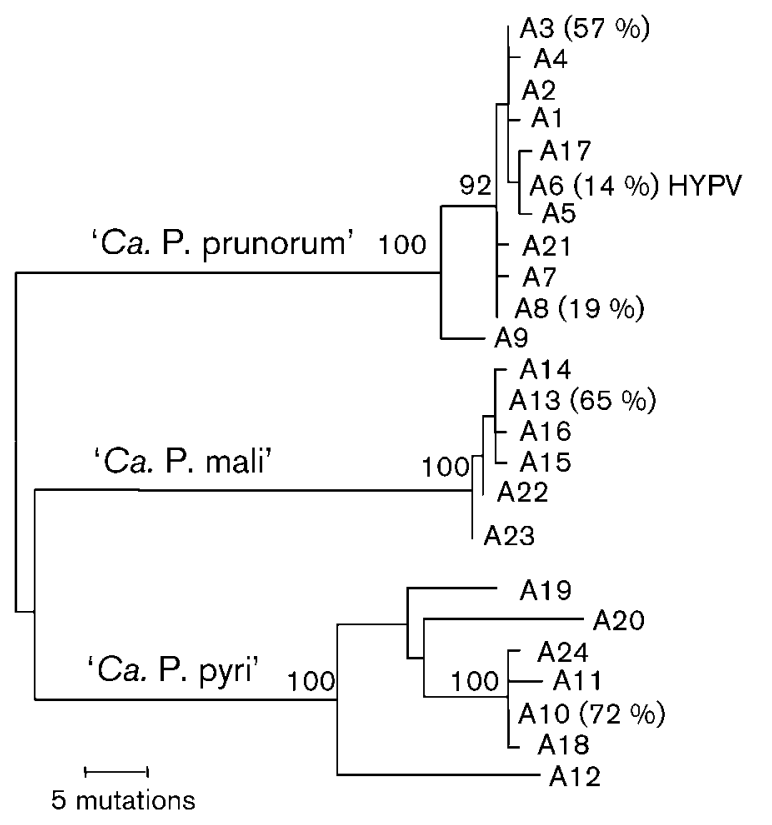

Fig. 1. Evolutionary relationships of ace $F$ for isolates of the group $16 \mathrm{SrX}$. The evolutionary history was inferred by using the maximum-parsimony method. The percentage of replicate trees in which the associated taxa clustered together in the bootstrap test (500 replicates) is shown next to the branches. Bootstrap values below 90 are omitted. The trees are drawn to scale; branch lengths were calculated using the average pathway method and represent the number of nucleotide changes over the whole sequence. Major genotypes are indicated (\%). HYPV, Hypo-virulent. and E22) clustered together within the same A6 genotype. This monophyletic clustering of hypo-virulent isolates indicates their possible single origin. Five ' $\mathrm{Ca}$. P. prunorum' genotypes A3, A5, A6, A8 and A21, out of 11 genotypes, could be detected in $C$. pruni insect vectors (Table 3). For ' $\mathrm{Ca}$. P. mali', among six genotypes differing in between one and three SNPs, the genotype A13 was predominant $(65 \%)$ and was detected in isolates from France, Italy and Germany (Table 3). For 'Ca. P. pyri', the seven genotypes showed a genetic divergence higher than that of ' $\mathrm{Ca}$. P. prunorum' genotypes, in the range of 1 to 24 SNPs. Genotype A10 represented $72 \%$ of the isolates and was detected in isolates from eight of the nine countries surveyed (Table 3). The six other genotypes were each found in a single country. Again, countries in the eastern part of the Mediterranean basin, such as Turkey or Lebanon, had specific ' $\mathrm{Ca}$. P. pyri' genotypes.

Sequences of the $p n p$ and $\sec Y$ markers were determined for 172 and 157 isolates of the three Candidatus species, respectively. Maximum-parsimony analyses were conducted with the sets of $p n p$ and $\sec Y$ sequences (Fig. 2). Phylogenetic trees obtained for both genes were consistent with the existence of the three described taxonomic species; all isolates of a given species were clustered on the same branch supported by high bootstrap values. The diversity of $p n p$ and $\sec Y$ was lower than that of aceF: 15 genotypes for $p n p$ and 12 genotypes for $\sec Y$ could be discriminated (Tables 4 and 5). For 'Ca. P. prunorum', two and three genotypes could be distinguished with $p n p$ and $\sec Y$, respectively, a much lower diversity when compared with the 11 aceF genotypes. The two pnp genotypes were also detected in C. pruni psyllids whereas only two of three $\sec Y$ genotypes were detected in C. pruni (Tables 4 and 5). For ' $\mathrm{Ca}$. P. mali', five and four genotypes were distinguished with $p n p$ and $\sec Y$ respectively, whereas for ' $\mathrm{Ca}$. P. pyri', eight and five genotypes were differentiated with the same markers. The most prevalent $p n p$ genotype was $\mathrm{P} 1$ in ' $\mathrm{Ca}$. $P$. prunorum' isolates originating from plant and insect. For secY, 'Ca. Phytoplasma' species-specific prevalences were seen: $\mathrm{S} 1$ and S2 in ' $\mathrm{Ca}$. $\mathrm{P}$. prunorum' isolates, S7 in 'Ca. P. pyri' isolates and S12 in 'Ca. P. mali' isolates.

The sequence of the imp marker was determined for 151 isolates of the three Candidatus species. Phylogenetic analysis using maximum parsimony showed 30 different genotypes (Fig. 3a). Clustering was again in agreement with the description of three Candidatus species; all isolates of a given species were clustered on the same branch supported by bootstrap values of 100 . Seven, nine and 14 genotypes could be distinguished for 'Ca. P. mali', 'Ca. P. pyri' and 'Ca. P. prunorum', respectively. The number of mutations between genotypes of the same species was much higher in 'Ca. P. pyri' and ' $\mathrm{Ca}$. P. mali' than in ' $\mathrm{Ca}$. P. prunorum'. For 'Ca. P. prunorum', the most prevalent genotype, genotype I1, was detected in 56 plant and insect samples coming from six countries (Table 6). Six genotypes were detected in two to four countries and eight genotypes were found in only one country. This was the case for genotypes 
Table 3. Origin of phytoplasma isolates with the ace $F$ genotype

\begin{tabular}{|c|c|c|c|c|c|c|}
\hline $\begin{array}{l}\text { Reference } \\
\text { isolate }\end{array}$ & Geographical origin* & $\begin{array}{c}\text { EMBL } \\
\text { accession no. }\end{array}$ & Pathogen & aceF genotype & No. of plants & No. of insects \\
\hline WJ3703/30 & Germany & FN598166 & 'Ca. P. prunorum' & A1 & 1 & 0 \\
\hline GSFY2 & Germany, France, Italy, Spain & FN598168 & 'Ca. P. prunorum' & A3 & 47 & 24 \\
\hline ESFYSpa01 & Spain & FN598169 & 'Ca. P. prunorum' & A4 & 3 & 0 \\
\hline $40-04 \mathrm{Cr}$ & Croatia, Italy & FN598170 & 'Ca. P. prunorum' & A5 & 1 & 1 \\
\hline $61-04 \mathrm{Cr}$ & Croatia & FN598172 & 'Ca. P. prunorum' & A7 & 1 & 0 \\
\hline ESFY & $\begin{array}{l}\text { Italy, Azerbaijan, Croatia, France, } \\
\text { Germany, Greece, Spain }\end{array}$ & FN598173 & 'Ca. P. prunorum' & A8 & 21 & 3 \\
\hline Azer10 & Azerbaijan & FN598174 & 'Ca. P. prunorum' & A9 & 2 & 0 \\
\hline Ya15 & Turkey & FN598175 & 'Ca. P. prunorum' & A 17 & 2 & 0 \\
\hline E60-11B & Italy & FN598176 & 'Ca. P. prunorum' & A21 & 0 & 1 \\
\hline $\mathrm{PP} / \mathrm{ZG} / 1$ & Croatia & FN598180 & 'Ca. P. pyri' & A18 & 2 & 0 \\
\hline $\mathrm{PI} / \mathrm{ZG} / 1$ & Croatia & FN598181 & 'Ca. P. pyri' & A19 & 0 & 1 \\
\hline PTK7 & Turkey & FN598182 & 'Ca. P. pyri' & A 20 & 0 & 1 \\
\hline $\mathrm{TR} / 1$ & Germany & FN598183 & 'Ca. P. pyri' & A24 & 1 & 0 \\
\hline AP-AT & Germany, France, Italy & FN598184 & 'Ca. P. mali' & A13 & 22 & 0 \\
\hline AP13 & Romania & FN598185 & 'Ca. P. mali' & A14 & 1 & 0 \\
\hline AP032-10 & France, Austria, Italy & FN598186 & 'Ca. P. mali' & A15 & 7 & 0 \\
\hline AP1Luca & Italy & FN598187 & 'Ca. P. mali' & A16 & 2 & 0 \\
\hline $\mathrm{TN} / 1$ & Italy & FN598188 & 'Ca. P. mali' & A 22 & 1 & 0 \\
\hline $\mathrm{NW} / 2$ & Germany & FN598189 & 'Ca. P. mali' & A23 & 1 & 0 \\
\hline
\end{tabular}

${ }^{\star}$ The aceF gene was isolated from samples isolated from the country/countries listed.

I5 and I26, respectively, which were detected in Azerbaijan and Turkey. Five genotypes were specifically detected in France. A gradient in the geographical distribution appeared between western and central Europe (Fig. 3b). Two of the Spanish genotypes (red and pale blue in Fig. 3) were only found in isolates from France and Germany, whereas the prevalent I1 and I2 genotypes (dark blue in Fig. 3) were absent in isolates from Spain. Genotypes of isolates from the eastern part of the Mediterranean basin, such as those detected in isolates from Turkey and Azerbaijan (brown and orange in Fig. 3) were not detected in central or western Europe.

\section{Identification of phytoplasma haplotypes reveals no geographical association}

For all four genes and all three phytoplasma candidate species, a total of 73 different haplotypes were detected (Supplementary Table S1, available with the online version of this paper). In the case of ' $C a$. P. prunorum', for which 118 isolates were fully genotyped, the haplotype network combining the four genetic loci aceF, pnp, imp and $\sec Y$ was built (Fig. 4). Thirty-four haplotypes were organized into a continuous network with A3-P1-I1-S1 and A3-P1-I9-S1
(Fig. 4, in grey) as founders representing $28 \%$ of the isolates. No relationship was found between the haplotype and the geographical origin of the plant (apricot, peach, Japanese plum) or psyllid. Interestingly, the four hypo-virulent isolates clustered on the same part of the haplotype network (Fig. 4, in black), again suggesting their common origin. Fifteen of the haplotypes were detected in psyllids and could possibly be epidemic if these insects were to be vectors. It was also noticeable that the major haplotype A3-P1-I1-S1 was only detected once in psyllids, whereas the less abundant haplotypes A3-P1-I1-S2 and A3-P1-I9-S2 were found twelve and seven times in the insect vector, respectively.

\section{Evidence for 'Ca. P. pyri' and 'Ca. P. prunorum' inter-species recombination}

The most striking result was obtained with three ' $\mathrm{Ca}$. P. pyri' isolates collected in Spain and Azerbaijan. Multilocus sequence analysis revealed that they possess both ' $\mathrm{Ca}$. P. pyri' and ' $\mathrm{Ca}$. P. prunorum' genetic markers (Fig. 5). For example, isolate Spa3 had aceF and imp genes of ' $\mathrm{Ca}$. P. prunorum' while its $p n p$ and $\sec Y$ genes corresponded to a 'Ca. P. pyri' genotype. Isolate Spa2 also had two genes corresponding to ' $\mathrm{Ca}$. P. prunorum' genotypes and two 
(a)

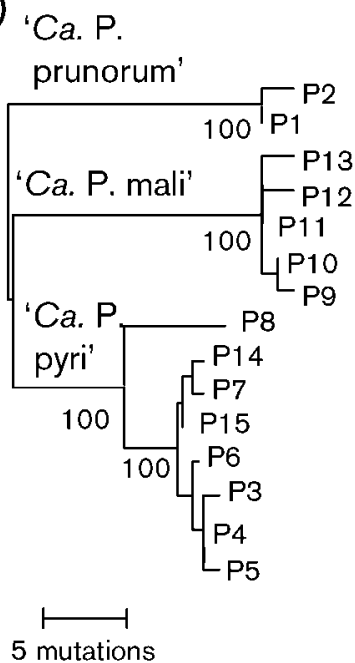

(b) 'Ca.P.
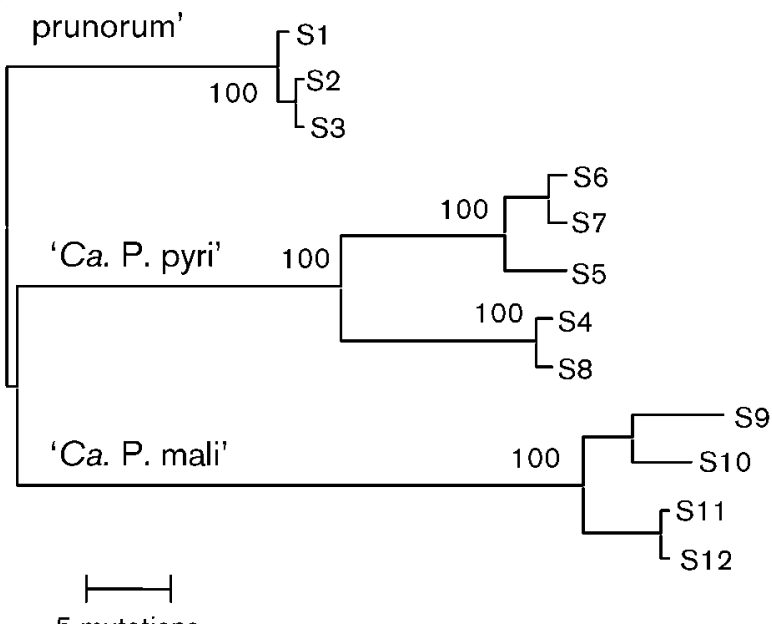

Fig. 2. Evolutionary relationships of $p n p(\mathrm{a})$ and $\sec Y(\mathrm{~b})$ for isolates of the group $16 \mathrm{SrX}$. The evolutionary history was inferred by using the maximum-parsimony method. The percentage of replicate trees in which the associated taxa clustered together in the bootstrap test (500 replicates) is shown next to the branches. Bootstrap values below 90 are omitted. The trees are drawn to scale; branch lengths were calculated using the average pathway method and represent the number of nucleotide changes over the whole sequence.

genes clustering within the ' $C a$. P. pyri' branch of the phylogenetic trees, whereas AZ-POI45 had only a ' $C a$. P. prunorum' $p n p$ gene and three other gene markers corresponding to ' $\mathrm{Ca}$. P. pyri'. Altogether, these results indicated that these isolates of ' $\mathrm{Ca}$. P. pyri' are inter-species recombinants. Surprisingly, for the Spa2 isolate, two different imp sequences could be detected, one corresponding to ' $\mathrm{Ca}$. P. prunorum' and one clustering with ' $\mathrm{Ca}$. P. pyri' imp sequences. This could not be associated with a mixed infection as only the $16 \mathrm{~S}$ rDNA sequence of ' $\mathrm{Ca} \mathrm{P}$. pyri' could be detected.

\section{DISCUSSION}

An MLST method has been developed and applied for typing temperate fruit tree phytoplasmas of the phylogenetic group $16 \mathrm{SrX}$. The most variable markers were imp and

Table 4. Origin of phytoplasma isolates with the pnp genotype

\begin{tabular}{|c|c|c|c|c|c|c|}
\hline $\begin{array}{l}\text { Reference } \\
\text { isolate }\end{array}$ & Geographical origin ${ }^{*}$ & $\begin{array}{c}\text { EMBL } \\
\text { accession no. }\end{array}$ & Pathogen & $\begin{array}{c}p n p \\
\text { genotype }\end{array}$ & $\begin{array}{l}\text { No. of } \\
\text { plants }\end{array}$ & $\begin{array}{l}\text { No. of } \\
\text { insects }\end{array}$ \\
\hline WJ3703-30 & Germany, Azerbaijan, Croatia, France, Italy, Spain & FN598190 & 'Ca. P. prunorum' & $\mathrm{P} 1$ & 75 & 30 \\
\hline ESFY & Italy, France, Germany, Azerbaijan & FN598191 & 'Ca. P. prunorum' & $\mathrm{P} 2$ & 14 & 2 \\
\hline PD & Germany, France, Lebanon, Spain & FN598192 & 'Ca. P. pyri' & P3 & 5 & 0 \\
\hline PD121Lib & Lebanon, Azerbaijan, Croatia, UK, Spain & FN598193 & 'Ca. P. pyri' & $\mathrm{P} 4$ & 9 & 1 \\
\hline PD84 & Italy, Lebanon & FN598194 & 'Ca. P. pyri' & P5 & 7 & 0 \\
\hline PD356-1 & France, UK & FN598195 & 'Ca. P. pyri' & P6 & 2 & 0 \\
\hline PD36AZ & Azerbaijan & FN598196 & 'Ca. P. pyri' & P7 & 1 & 0 \\
\hline PD2Luca & Italy, Spain & FN598197 & 'Ca. P. pyri' & P8 & 2 & 0 \\
\hline $\mathrm{PP} / \mathrm{ZG} / 1$ & Croatia & FN598198 & 'Ca. P. pyri' & P14 & 2 & 0 \\
\hline $\mathrm{PI} / \mathrm{ZG} / 1$ & Croatia & FN598199 & 'Ca. P. pyri' & P15 & 1 & 1 \\
\hline AP-AT & Germany, France & FN598200 & 'Ca. P. mali’ & P9 & 2 & 0 \\
\hline AP15 & Italy, France & FN598201 & 'Ca. P. mali' & $\mathrm{P} 10$ & 3 & 0 \\
\hline AP28 & Switzerland, France, Italy, Romania & FN598202 & 'Ca. P. mali' & P11 & 6 & 0 \\
\hline AP032-10 & France, Austria, Italy & FN598203 & 'Ca. P. mali' & $\mathrm{P} 12$ & 4 & 0 \\
\hline AP1Luca & Italy & FN598204 & 'Ca. P. mali' & $\mathrm{P} 13$ & 2 & 0 \\
\hline
\end{tabular}

*The pnp gene was isolated from samples isolated from the country/countries listed. 
Table 5. Origin of phytoplasma isolates with the $\sec Y$ genotype

\begin{tabular}{|c|c|c|c|c|c|c|}
\hline $\begin{array}{l}\text { Reference } \\
\text { isolate }\end{array}$ & Geographical origin ${ }^{\star}$ & $\begin{array}{c}\text { EMBL } \\
\text { accession no. }\end{array}$ & Pathogen & $\sec Y$ genotype & $\begin{array}{l}\text { No. of } \\
\text { plants }\end{array}$ & $\begin{array}{l}\text { No. of } \\
\text { insects }\end{array}$ \\
\hline GSFY & Germany, France, Italy, Spain & FN598205 & 'Ca. P. prunorum' & S1 & 52 & 3 \\
\hline $14 \mathrm{MY}$ & France, Croatia, Germany, Spain & FN598207 & 'Ca. P. prunorum' & S3 & 6 & 0 \\
\hline PDSpa2 & Spain & FN598208 & 'Ca. P. pyri' & S4 & 1 & 0 \\
\hline PD36Az & Azerbaijan & FN598209 & 'Ca. P. pyri' & S5 & 1 & 0 \\
\hline $\mathrm{PD}$ & Germany, France, UK, Italy, Lebanon, Spain & FN598211 & 'Ca. P. pyri' & S7 & 10 & 0 \\
\hline PD2Luca & Italy, Spain & FN598212 & 'Ca. P. pyri' & S8 & 2 & 0 \\
\hline AP-AT & Germany & FN598213 & 'Ca. P. mali' & S9 & 3 & 0 \\
\hline AP4Luca & Italy, Austria & FN598214 & 'Ca. P. mali' & S10 & 2 & 0 \\
\hline AP032-10 & France & FN598215 & 'Ca. P. mali' & S11 & 1 & 0 \\
\hline AP15 & Italy, France, Romania & FN598216 & 'Ca. P. mali' & S12 & 10 & 0 \\
\hline
\end{tabular}

${ }^{\star}$ The $\sec Y$ gene was isolated from samples isolated from the country/countries listed.

aceF but should not be solely used, because different clusterings were obtained with the markers $p n p$ and $\sec Y$. The efficiency of this typing system was illustrated by the discrimination of 34 different haplotypes within the ' $C a$. P. prunorum' species. MLST is particularly useful for epidemiological studies especially to compare the genotypes present in the wild and cultivated compartments, for example in the case of 'Ca. P. prunorum' in Prunus spinosa versus apricot or Japanese plum orchards. MLST of the phytoplasmas detected in the psyllid vector will then show whether ' $\mathrm{Ca}$. P. prunorum' is transmitted from wild Prunus to orchards. Fine genotyping can also be useful to trace the route of propagation by nurseries. The dominant haplotype A3-P1-I1-S1 that was very rarely detected in psyllid vectors could have spread by the propagation of infected plant material. Phylogenetic studies can also help to explore the origin of related phytoplasmas living in different hosts as has been illustrated with the common origin of alder and grapevine phytoplasmas in the $16 \mathrm{SrV}$ phylogenetic group (Arnaud et al., 2007). MLST may contribute to functional studies of the biological traits of phytoplasmas. For example, the hypo-virulence trait in 'Ca. P. prunorum' (Kison \& Seemüller, 2001) has been well characterized in the four French isolates used in this study and all of them had the same aceF genotype, A6, but different $p n p$, secY and imp genotypes. This shows that the A6 genotype is not carried by a clonal strain but by a diversified cluster of isolates. It is not yet known to what extent the A6 genotype is linked to the hypo-virulent trait. Are the other ' $\mathrm{Ca}$. P. prunorum' isolates with genotype A6 also hypo-virulent? Biological characterization of more isolates is needed to establish a firm correlation between the A6 genotype and the hypo-virulent trait. Two of the 'Ca. P. prunorum' isolates tested in the present study infect sensitive apricot varieties that remained symptomless for many years. However, these isolates are genotype A8, showing at least that the hypo-virulent trait does not have a monophyletic origin. The aceF gene may be directly responsible for hypo-virulence since the AceF protein is involved in glycolysis. Alternatively, a gene genetically linked to aceF may determine hypo-virulence. In the A6 genotype, a punctual mutation replaces a threonine with an asparagine at position 189 in the E2 component of the pyruvate dehydrogenase. The effect of this mutation is unknown. The possibility that hypo-virulent isolates are impaired in carbon metabolism can be envisaged. Glycolysis is a pathway essential for phytoplasmas which have a reduced physiology as shown by the analysis of their small genome content (Bai et al., 2006; Oshima et al., 2004; Tran-Nguyen et al., 2008). This pathway is only partially present in ' $C a$. P. mali' strain AT, as deduced from the sequence of its linear chromosome (Kube et al., 2008) even though the functional activity of the remaining half of the glycolysis pathway is still unknown.

Due to the low level of similarity between imp sequences of the different Candidatus species, it could be stressed that they do not correspond to orthologous genes. Despite the low identity at the nucleotide level, the three imp genes are certainly orthologues and not paralogues, because identity at the protein level ranges from 43 to $49 \%$ between the three phytoplasma species. In addition, only one copy of imp exists in the sequenced genome of ' $\mathrm{Ca}$. P. mali'. It has recently been demonstrated that imp genes are highly variable and submitted to strong diversifying selection (Kakizawa et al., 2009). Nevertheless we cannot exclude the possibility of hidden paralogy, in which orthologues would have been duplicated and would have been lost further. It does not, however, affect the results of the genotyping and its analysis.

For the first time to our knowledge, a recombination between phytoplasmas has been shown. We showed that ' $C a$. P. pyri' and ' $\mathrm{Ca}$ P. prunorum' have undergone recombination. When the results were first obtained, we envisaged the possibility of a PCR cross-over contamination despite the numerous measures taken in our laboratory to 


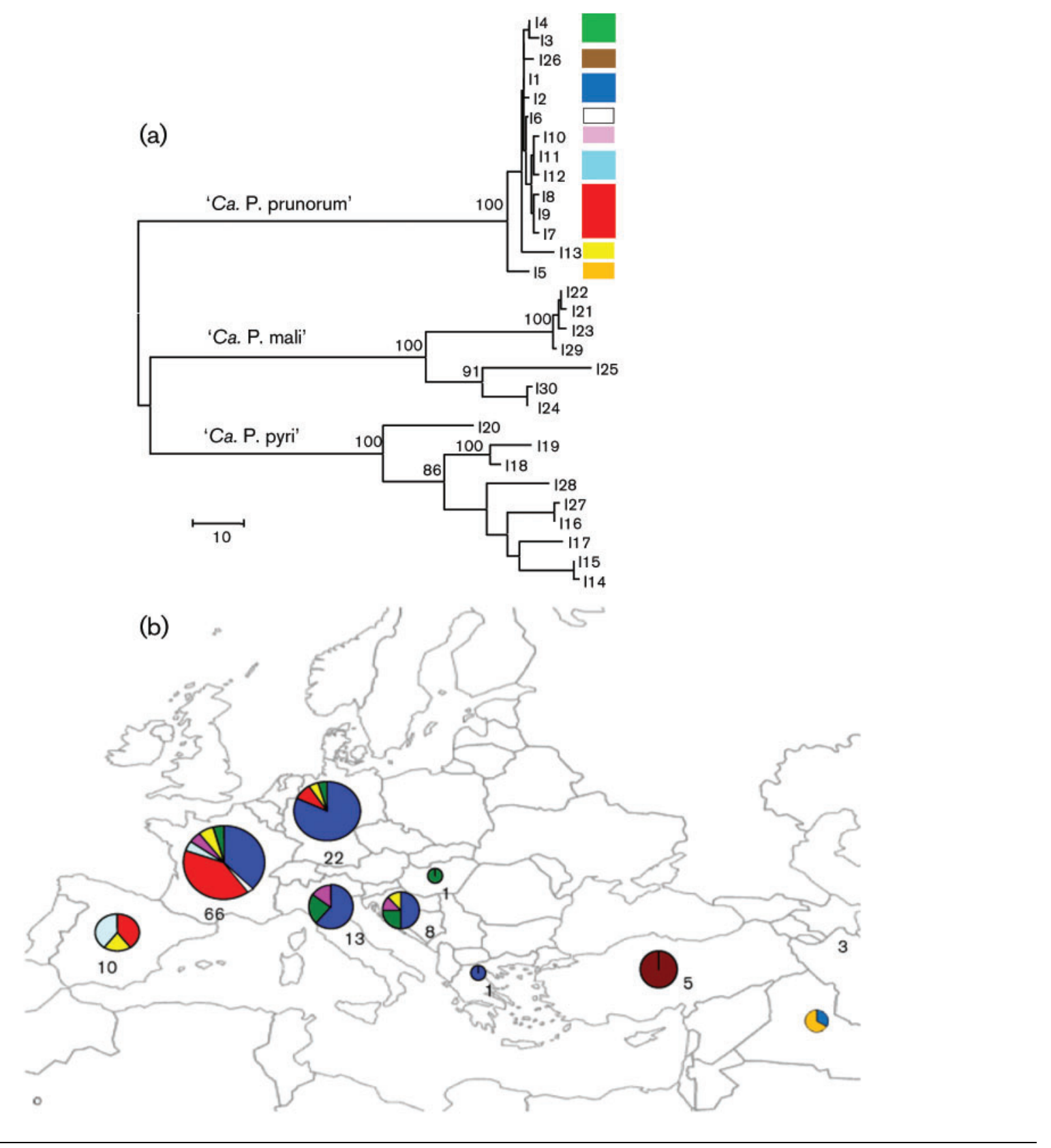

Fig. 3. Genetic variability of imp (a) and geographical distribution of 'Ca. P. prunorum' imp genotypes (b). (a) Evolutionary relationships of $i m p$ for isolates of the group $16 \mathrm{SrX}$. The evolutionary history was inferred by using the maximum-parsimony method. The percentage of replicate trees in which the associated taxa clustered together in the bootstrap test (500 replicates) is shown next to the branches. Bootstrap values below 90 are omitted. The trees are drawn to scale; branch lengths were calculated using the average pathway method and represent the number of nucleotide changes over the whole sequence. (b) Distribution of 'Ca. P. prunorum' imp genotypes in the northern Euro-Mediterranean basin. Numbers below the circles indicate the total number of isolates per country. The colour legend is given in (a).

prevent such artefacts. So, the experiment was repeated but the same results were obtained and still the negative PCR controls remained negative. So our results were reproducible and we finally excluded the possibility of a PCR contamination when looking in detail at the result of the Azerbaijanese isolate POI45. This isolate is recombinant for the $p n p$ gene and its $p n p$ sequence is unique, with several mutations distinguishing this isolate from the other known pnp genotypes (P1 and P2). If this result was due to PCR contamination, the sequence should have been that of P1 or P2. For isolate Spa2, in which we detected two different copies of imp, we could exclude mixed infection between ' $\mathrm{Ca}$. P. pyri' and 'Ca. P. prunorum' after 16SrDNA sequencing, but we could not 
Table 6. Origin of phytoplasma isolates with the imp genotype

\begin{tabular}{|c|c|c|c|c|c|c|}
\hline $\begin{array}{l}\text { Reference } \\
\text { isolate }\end{array}$ & Geographical origin & $\begin{array}{c}\text { EMBL } \\
\text { accession no. }\end{array}$ & Pathogen & $\begin{array}{c}\text { imp } \\
\text { genotype }\end{array}$ & $\begin{array}{l}\text { No. of } \\
\text { plants }\end{array}$ & $\begin{array}{l}\text { No. of } \\
\text { insects }\end{array}$ \\
\hline ESFY & Italy, Azerbaijan, Croatia, France, Germany, Greece & FN600707 & 'Ca. P. prunorum' & $\mathrm{I} 1$ & 41 & 15 \\
\hline WJ3889-42 & Germany & FN600709 & 'Ca. P. prunorum' & I3 & 1 & 0 \\
\hline $40-04 \mathrm{Cr}$ & Croatia, France, Italy, Hungary & FN600710 & 'Ca. P. prunorum' & I4 & 8 & 0 \\
\hline Azer10 & Azerbaijan & FN600711 & 'Ca. P. prunorum' & I5 & 2 & 0 \\
\hline $05 \mathrm{MY}$ & France & FN600713 & 'Ca. P. prunorum' & I7 & 1 & 0 \\
\hline G32 & France & FN600714 & 'Ca. P. prunorum' & I8 & 1 & 0 \\
\hline B7 & France, Germany, Spain & FN600715 & 'Ca. P. prunorum' & I9 & 20 & 11 \\
\hline $13 \mathrm{MY}$ & France, Croatia, Italy & FN600716 & 'Ca. P. prunorum' & $\mathrm{I} 10$ & 3 & 3 \\
\hline ESFYSpa01 & France, Spain & FN600717 & 'Ca. P. prunorum' & I11 & 3 & 2 \\
\hline $01 \mathrm{MY}$ & France & FN600718 & 'Ca. P. prunorum' & $\mathrm{I} 12$ & 1 & 0 \\
\hline PD36AZ & Azerbaijan, Croatia & FN600723 & 'Ca. P. pyri' & I16 & 2 & 0 \\
\hline PD121Lib & Lebanon & FN600724 & 'Ca. P. pyri' & $\mathrm{I} 17$ & 3 & 0 \\
\hline PD33Lib & Lebanon, Azerbaijan & FN600725 & 'Ca. P. pyri' & $\mathrm{I} 18$ & 1 & 0 \\
\hline $\mathrm{PD}$ & Germany, Croatia, Italy & FN600726 & 'Ca. P. pyri' & I19 & 4 & 0 \\
\hline PDSpa2 & Spain, France & FN600727 & 'Ca. P. pyri' & $\mathrm{I} 20$ & 1 & 0 \\
\hline $\mathrm{KT} / 1$ & Croatia & FN600728 & 'Ca. P. pyri' & $\mathrm{I} 27$ & 2 & 1 \\
\hline $\mathrm{PI} / \mathrm{ZG} / 1$ & Croatia & FN600729 & 'Ca. P. pyri' & $\mathrm{I} 28$ & 0 & 1 \\
\hline AP032-10 & France, Austria, Germany, Italy & FN600730 & 'Ca. P. mali' & $\mathrm{I} 21$ & 12 & 0 \\
\hline AP13 & Romania & FN600731 & 'Ca. P. mali' & $\mathrm{I} 22$ & 2 & 0 \\
\hline AP15 & Italy, Germany & FN600732 & 'Ca. P. mali' & $\mathrm{I} 23$ & 4 & 0 \\
\hline AP-AT & Germany, France & FN600733 & 'Ca. P. mali' & $\mathrm{I} 24$ & 2 & 0 \\
\hline
\end{tabular}

*The imp gene was isolated from samples isolated from the country/countries listed.

reject the possibility of a mixed infection between two ' $\mathrm{Ca}$. P. pyri' isolates, one isolate being recombinant, the other not. Another possibility could be that an isolate carries two imp genes, one copy having diverged in its function. But the question remains about the mechanism of such recombinations. Until the publication of the ' $\mathrm{Ca}$. P. mali' genome, the ability of phytoplasmas to perform recombination was questionable because they lack the genetic information to perform homologous recombination (Bai et al., 2006; Oshima et al., 2004). Nevertheless, it was discovered that ' $C a$. P. mali' has an extended set of genes for homologous recombination, including the essential gene $\operatorname{rec} A$ (Kube et al., 2008). In addition, all members of the $16 \mathrm{SrX}$ group have a linear chromosome, a property that in combination with the

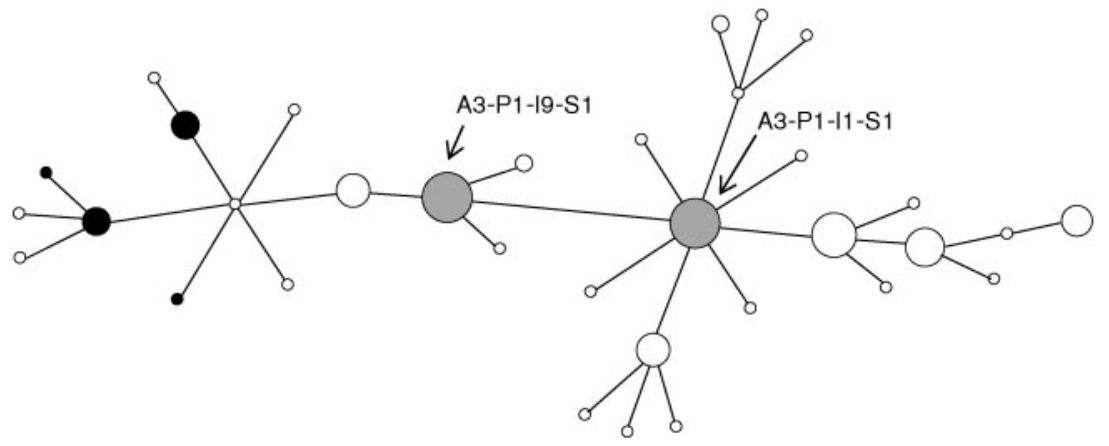

Fig. 4. Haplotype network of 'Ca. P. prunorum' isolates. Grey indicates founder haplotypes and black indicates hypo-virulent isolates. 


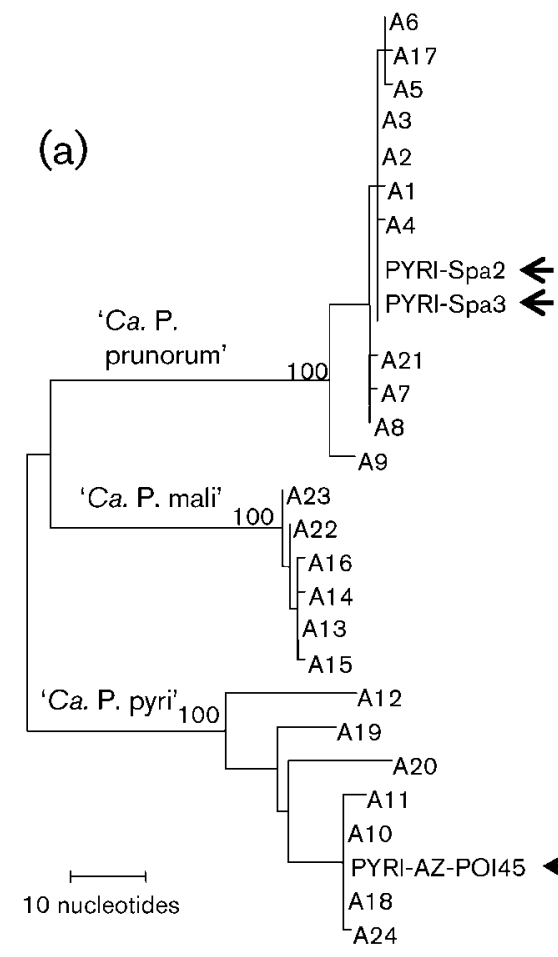

(b)

(c)

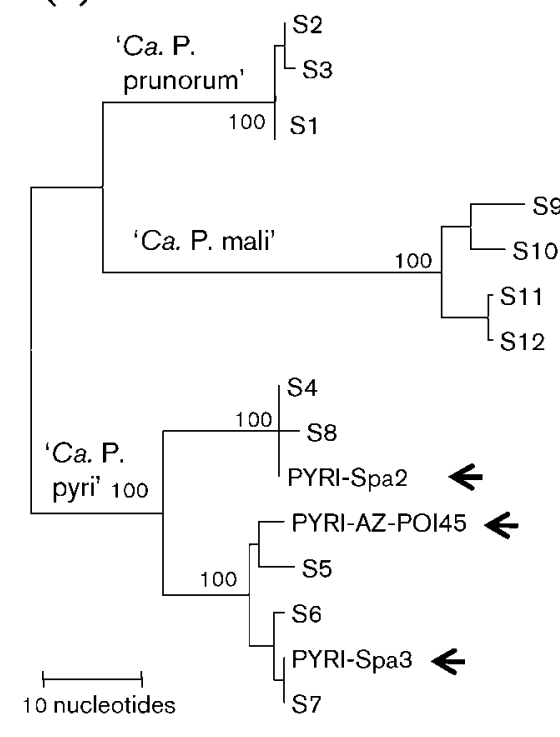

(d)
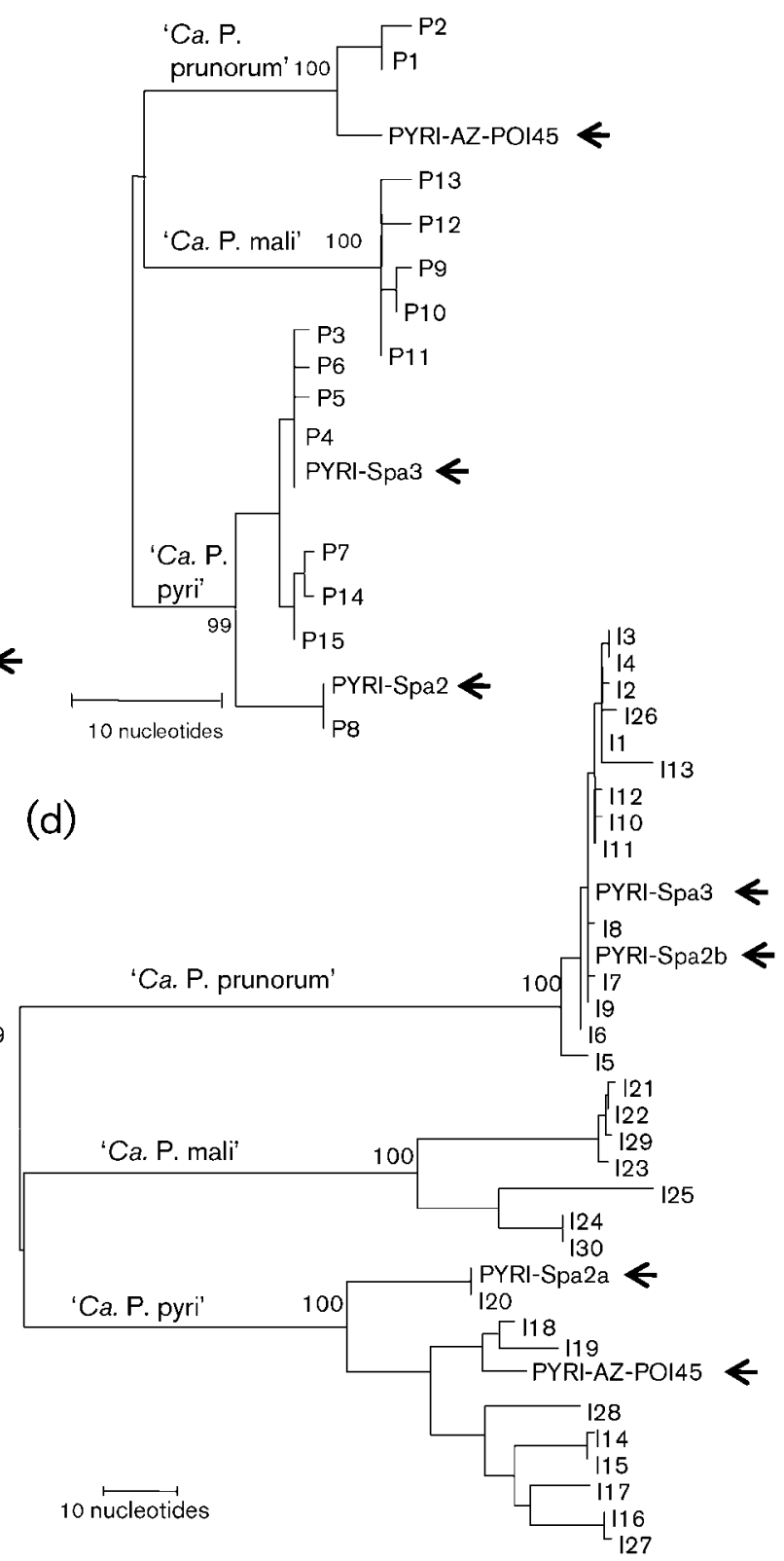

Fig. 5. Evolutionary relationships of $\operatorname{ace} F(\mathrm{a}), \operatorname{pnp}(\mathrm{b}), \sec Y(\mathrm{c})$ and $i m p(\mathrm{~d})$ for recombinant 'Ca. P. pyri' and isolates of the group $16 \mathrm{SrX}$. The evolutionary history was inferred by using the maximum-parsimony method. The percentage of replicate trees in which the associated taxa clustered together in the bootstrap test (500 replicates) is shown next to the branches. Bootstrap values below 90 are omitted. The trees are drawn to scale; branch lengths were calculated using the average pathway method and represent the number of nucleotide changes over the whole sequence. Arrows indicate 'Ca. P. pyri' recombinants.

presence of multiple repeated genes such as $h f l B$ (Schneider \& Seemüller, 2009), a gene known to be present as multiple copies in all known phytoplasma genomes (Kube et al., 2008; Oshima et al., 2004), can facilitate the exchange of a full chromosome arm through a single cross-over. Such a simple recombination event would lead to the exchange of many gene markers at the same time. However, to allow recombination between two species, they have to share a common host. 'Ca. P. pyri' can be transmitted and multiplies in peach where it induces the peach yellow leaf 
roll (Blomquist \& Kirkpatrick, 2002a; Purcell et al., 1981). Peach is a common host for ' $\mathrm{Ca}$. P. prunorum' in the north of the Euro-Mediterranean area; it is therefore probable that peach was the host in which the inter-species recombination occurred. Recombination might also have occurred in a common insect vector, such as $C$. pyri, which is more polyphagous in autumn and might acquire both phytoplasmas from their respective host plant. Because none of the three 'Ca. P. pyri' recombinants had the same MLST genotype, it is likely that the recombination event is quite frequent. Indeed, it represented three cases from two distinct geographical areas over 19 different ' $C a$. P. pyri' isolates tested. After their appearance, recombinants had been naturally transmitted back to pear by psyllids, in which they were finally detected. One could certainly consider that if recombination occurs between species it could also occur within species. We cannot confirm such a phenomenon because, despite incongruence between the phylogenetic trees of the different markers, the bootstrap validity levels were not high enough to consider it evident.

\section{ACKNOWLEDGEMENTS}

We greatly acknowledge the French Embassy in Baku and FEBS for supporting G. B. This work was financially supported by grants from the French National Research Agency, programme ECOGER and the INRA department of Plant Health and Environment and by the Programme Sectorial I+D, M.A.P.A., Spain (grant RT2009-00070). This work was partly carried out in the frame of the SEE-ERANET network 'global epidemiology of phytoplasma diseases of economical importance in south-eastern Europe'. We thank M. Kölber and I. Ember (both PHYTOLAB, Budapest, Hungary), P. Gentit (CTIFL, Bergerac, France), and N. Katis and V. Maliogka (both Aristotle University of Thessalonoki, Greece) for providing phytoplasma isolates and H. Bahriz, Michel Yvon, J. Peyre and P. Limon for excellent technical assistance.

\section{REFERENCES}

Arnaud, G., Malembic-Maher, S., Salar, P., Bonnet, P., Maixner, M., Marcone, C., Boudon-Padieu, E. \& Foissac, X. (2007). Multilocus sequence typing confirms the close genetic inter-relatedness between three distinct flavescence dorée phytoplasma strain clusters and group $16 \mathrm{SrV}$ phytoplasmas infecting grapevine and alder in Europe. Appl Environ Microbiol 73, 4001-4010.

Bai, X. D., Zhang, J. H., Ewing, A., Miller, S. A., Jancso Radek, A., Shevchenko, D. V., Tsukerman, K., Walunas, T., Lapidus, A. \& other authors (2006). Living with genome instability: the adaptation of phytoplasmas to diverse environments of their insect and plant hosts. J Bacteriol 188, 3682-3696.

Battle, A., Lavina, A., Marta, F. \& Medina, V. (1999). Incidence and epidemiology of pear decline in North-Eastern Spain. First Internet Conference of Phytopathogenic Mollicutes.

Blomquist, C. L. \& Kirkpatrick, B. C. (2002a). Identification of phytoplasma taxa and insect vectors of peach yellow leaf roll disease in California. Plant Dis 86, 759-763.

Blomquist, C. L. \& Kirkpatrick, B. C. (2002b). Frequency and seasonal distribution of pear psylla infected with the pear decline phytoplasma in California pear orchards. Phytopathology 92, 1218-1226.
Bonfield, J. K., Smith, K. F. \& Staden, R. (1995). A new DNA sequence assembly program. Nucleic Acids Res 23, 4992-4999.

Carraro, L., Osler, R., Refatti, E. \& Poggi-pollini, C. (1988). Transmission of the possible agent of apple proliferation to Vinca rosea by dodder. Riv Pat Végetale. IV, 43-52.

Carraro, L., Osler, R., Loi, N., Ermacora, P. \& Refatti, E. (1998). Transmission of European stone fruit yellows phytoplasma by Cacopsylla pruni. J Plant Pathol 80, 233-239.

Choueiri, E., Salar, P., Jreijiri, F., Zammar, S. E., Danet, J. L. \& Foissac, X. (2007). First report and characterization of pear decline phytoplasma on pear in Lebanon. J Plant Pathol 89, S75.

Ciccotti, A. M., Bianchedi, P. L., Bragagna, P., Deromedi, M., Filippi, M., Forno, F. \& Mattedi, L. (2007). Transmission of 'Candidatus Phytoplasma mali' by root bridges under natural and experimental conditions. Bull Insectol 60, 387-388.

Cimerman, A., Arnaud, G. \& Foissac, X. (2006). Stolbur phytoplasma genome survey achieved using a suppression subtractive hybridization approach with high specificity. Appl Environ Microbiol 72, 3274-3283.

Cornaggia, D., Gentit, P., Boyé, R. \& Desvignes, J. C. (1995). A new phytoplasma disease of apricot tree: the peach vein clearing. Acta Hortic 386, 448-453.

Danet, J. L., Bahriz, H., Cimerman, A. \& Foissac, X. (2008). New molecular typing tools to monitor fruit tree phytoplasma variability in the $16 \mathrm{SrX}$ taxonomic group. XXth International symposium on virus and virus-like diseases of temperate fruit crops. Acta Hortic 781, 343349.

Davies, D. L., Guise, C. M., Clark, M. F. \& Adams, A. N. (1992). Parry's disease of pears is similar to pear decline and is associated with mycoplasma-like organisms transmitted by Cacopsylla pyricola. Plant Pathol 41, 195-203.

Ewing, B. \& Green, P. (1998). Base-calling of automated sequencer traces using phred. II. Error probabilities. Genome Res 8, 186-194.

Ewing, B., Hillier, L., Wendl, M. \& Green, P. (1998). Base-calling of automated sequencer traces using phred. I. Accuracy assessment. Genome Res 8, 175-185.

Feil, E. J., Li, B. C., Aanensen, D. M., Hanage, W. P. \& Spratt, B. G. (2004). евURST: inferring patterns of evolutionary descent among clusters of related bacterial genotypes from multilocus sequence typing data. J Bacteriol 186, 1518-1530.

Frisinghelli, C., Delaiti, L., Grando, M. S., Forti, D. \& Vindimian, M. E. (2000). Cacopsylla costalis (Flor 1861), as a vector of apple proliferation in Trentino. J Phytopathol 148, 425-431.

Gordon, D., Abajian, C. \& Green, P. (1998). Consed: a graphical tool for sequence finishing. Genome Res 8, 195-202.

Gundersen, D. E. \& Lee, I.-M. (1996). Ultrasensitive detection of phytoplasmas by nested-PCR assays using two universal primer pairs. Phytopathol Mediterr 35, 144-151.

Jarausch, B. \& Jarausch, W. (2009). Psyllid vectors and their control. In Phytoplasmas: Genomes, Plant Hosts and Vectors, pp. 250-271. Edited by P. Weintraub \& P. Jones. Wallingford: CABI.

Jarausch, W., Saillard, C., Dosba, F. \& Bové, J. M. (1994). Differentiation of mycoplasmalike organisms (MLOs) in European fruit-trees by PCR using specific primers derived from the sequence of a chromosomal fragment of the apple proliferation MLO. Appl Environ Microbiol 60, 2916-2923.

Jarausch, W., Lansac, M., Saillard, C., Broquaire, J. M. \& Dosba, F. (1998). PCR assay for specific detection of European stone fruit yellows phytoplasmas and its use for epidemiological studies in France. Eur J Plant Pathol 104, 17-27.

Jarausch, W., Danet, J. L., Labonne, G., Dosba, F., Broquaire, J. M., Saillard, C. \& Garnier, M. (2001). Mapping the spread of apricot 
chlorotic leaf roll (ACLR) in southern France and implication of Cacopsylla pruni as a vector of European stone fruit yellows (ESFY) phytoplasmas. Plant Pathol 50, 782-790.

Jensen, D. D., Griggs, W. H., Gonzales, C. Q. \& Schneider, H. (1964). Pear decline virus transmission by pear psylla. Phytopathology 54, 1346-1351.

Kakizawa, S., Oshima, K., Ishii, Y., Hoshi, A., Maejima, K., Jung, H. Y., Yamaji, Y. \& Namba, S. (2009). Cloning of immunodominant membrane protein genes of phytoplasmas and their in planta expression. FEMS Microbiol Lett 293, 92-101.

Kison, H. \& Seemüller, E. (2001). Differences in strain virulence of the European stone fruit yellows phytoplasma and susceptibility of stone fruit trees on various rootstocks to this pathogen. J Phytopathol 149, 533-541.

Kube, M., Schneider, B., Kuhl, H., Dandekar, T., Heitmann, K., Migdoll, A. M., Reinhardt, R. \& Seemüller, E. (2008). The linear chromosome of the plant-pathogenic mycoplasma 'Candidatus Phytoplasma mali'. BMC Genomics 9, 306.

Kumar, S., Tamura, K., Jakobsen, I. B. \& Nei, M. (2001). MEGA2: Molecular Evolutionary Genetics Analysis (MEGA) software. Bioinformatics 17, 1244-1245.

Lee, I. M., Davis, R. E. \& Gundersen-Rindal, D. E. (2000). Phytoplasma: phytopathogenic mollicutes. Annu Rev Microbiol 54, 221-255.

Liu, H.-L., Chen, C.-C. \& Lin, C.-P. (2007). Detection and identification of the phytoplasma associated with pear decline in Taiwan. Eur $J$ Plant Pathol 117, 281-291.

Lorenz, K.-H., Dosba, F., Poggi-Pollini, C., Llacer, G. \& Seemüller, E. (1994). Phytoplasma diseases of Prunus species in Europe are caused by genetically similar organisms. Z Pflanzenkr Pflanzenchutz 101, 567575 .

Lorenz, K.-H., Schneider, B., Ahrens, U. \& Seemüller, E. (1995). Detection of the apple proliferation and pear decline phytoplasmas by PCR amplification of ribosomal and nonribosomal DNA. Phytopathology 85, 771-776.

Maiden, M. C. J., Bygraves, J. A., Feil, E., Morelli, G., Russell, J. E., Urwin, R., Zhang, Q., Zhou, J., Zurth, K. \& other authors (1998). Multilocus sequence typing: a portable approach to the identification of clones within populations of pathogenic microorganisms. Proc Natl Acad Sci U S A 95, 3140-3145.

Maixner, M., Ahrens, U. \& Seemüller, E. (1995). Detection of the German grapevine yellows (Vergilbungskrankheit) MLO in grapevine, alternative hosts and a vector by a specific PCR procedure. Eur J Plant Pathol 101, 241-250.

Malinowski, T., Zandarski, J., Komorowska, B. \& Zawadzka, B. (1996). Detection of pear decline phytoplasma in declining pear trees in Poland. Plant Dis 80, 464.

Marcone, C., Hergenhahn, F., Ragozzino, A. \& Seemüller, E. (1999). Dodder transmission of pear decline, European stone fruit yellows, rubus stunt, Picris echioides yellows and cotton phyllody phytoplasmas to periwinkle. J Phytopathol 147, 187-192.

Marcone, C., Jarausch, B. \& Jarausch, W. (2010). Candidatus Phytoplasma prunorum, the causal agent of European stone fruit yellows: an overview. J Plant Pathol 92, 19-34.

Marwitz, R., Petzold, H. \& Ozel, M. (1974). Untersuchungen zur ubertragbarkeit des möglichen erregers der triebsucht des apfels auf einen krautigen wirt. J Phytopathol 81, 85-91 (in German).
Morton, A., Davies, D. L., Blomquist, C. L. \& Barbara, D. J. (2003). Characterization of homologues of the apple proliferation immunodominant membrane protein gene from three related phytoplasmas. Mol Plant Pathol 4, 109-114.

Morvan, G., Castelain, C., Chastellière, M. G. \& Audergon, J. M. (1991). An account of the attempts at controling apricot chlorotic leaf roll with cross protection. Acta Hortic 293, 555-561.

Oshima, K., Kakizawa, S., Nishigawa, H., Jung, H. Y., Wei, W., Suzuki, S., Arashida, R., Nakata, D., Miyata, S. \& other authors (2004). Reductive evolution suggested from the complete genome sequence of a plantpathogenic phytoplasma. Nat Genet 36, 27-29.

Purcell, A. H., Nyland, G., Raju, B. C. \& Heringor, M. R. (1981). Peach yellow leaf roll epidemic in Northern California: effects of peach cultivar, tree age and proximity to pear orchards. Plant Dis 65, 365368.

Sambrook, J., Fritsch, E. F. \& Maniatis, T. (1989). Molecular Cloning: a Laboratory Manual, 2nd edn. Cold Spring Harbor, NY: Cold Spring Harbor Laboratory.

Schneider, B. \& Seemüller, E. (2009). Strain differentiation of Candidatus Phytoplasma mali by SSCP and sequence analyses of the hflB gene. J Plant Pathol 91, 103-112.

Seemüller, E. (1990). Apple proliferation. In Compendium of Apple and Pear Diseases edited by A. L. Jones \& H. S. Aldwinkle, pp. 67-68. St Paul, USA: American Phytopathological Society.

Seemüller, E. \& Schneider, B. (2004). 'Candidatus Phytoplasma mali', 'Candidatus Phytoplasma pyri' and 'Candidatus Phytoplasma prunorum', the causal agents of apple proliferation, pear decline and European stone fruit yellows, respectively. Int J Syst Evol Microbiol 54, 1217-1226.

Seemüller, E. \& Schneider, B. (2007). Differences in virulence and genomic features of strains of 'Candidatus Phytoplasma mali', the apple proliferation agent. Phytopathology 97, 964-970.

Sertkaya, G., Martini, M. \& Osler, R. (2008). First report of Candidatus phytoplasma mali in Turkey. J Plant Pathol 90, 143.

Sharbatkhari, M., Bahar, M. \& Ahoonmanesh, A. (2008). Detection of the phytoplasmal agent of pear decline in Iran, Isfahan province, using nested-PCR. International Journal of Plant Production 2, 167173.

Thompson, J. D., Higgins, D. G. \& Gibson, T. J. (1994). CLUSTAL W: improving the sensitivity of progressive multiple sequence alignment through sequence weighting, position-specific gap penalties and weight matrix choice. Nucleic Acids Res 22, 4673-4680.

Tran-Nguyen, L. T. T., Kube, M., Schneider, B., Reinhardt, R. \& Gibb, K. S. (2008). Comparative genome analysis of "Candidatus Phytoplasma australiense" (subgroup tuf-Australia I; rp-A) and "Ca. Phytoplasma asteris" strains OY-M and AY-WB. J Bacteriol 190, 3979-3991.

Urwin, R. \& Maiden, M. C. J. (2003). Multi-locus sequence typing: a tool for global epidemiology. Trends Microbiol 11, 479-487.

Weintraub, P. G. \& Beanland, L. (2006). Insect vectors of phytoplasmas. Annu Rev Entomol 51, 91-111.

Weisburg, W. G., Tully, J. G., Rose, D. L., Petzel, J. P., Oyaizu, H., Yang, D., Mandelco, L., Sechrest, J., Lawrence, T. G. \& other authors (1989). A phylogenetic analysis of the mycoplasmas: basis for their classification. J Bacteriol 171, 6455-6467.

Edited by: C. A. Boucher 